Article

\title{
Effect of Ornamental Plants, Seasonality, and Filter Media Material in Fill-and-Drain Constructed Wetlands Treating Rural Community Wastewater
}

\author{
Sergio A. Zamora-Castro ${ }^{1}\left(\right.$, José Luis Marín-Muñiz ${ }^{2, *} \mathbb{C}^{\text {, Luis Sandoval }}{ }^{3}{ }^{(0)}$, \\ Monserrat Vidal-Álvarez ${ }^{2}$ (D) and Juan Manuel Carrión-Delgado 4 \\ 1 Facultad de Ingeniería de la Construcción y el Hábitat, Universidad Veracruzana, \\ Bv. Adolfo Ruíz Cortines 455, Costa Verde, Boca del Rio, Veracruz 94294, Mexico; szamora@uv.mx \\ 2 Academia Desarrollo Regional Sustentable, El Colegio de Veracruz, Carrillo Puerto No. 26, Xalapa, \\ Veracruz 91000, Mexico; monserrat.vidal@gmail.com \\ 3 Departamento de Ingeniería Civil, Tecnológico Nacional de México/Instituto Tecnológico Superior de \\ Misantla, Km. 1.8 Carretera a Loma del Cojolite Misantla, Veracruz 93821, Mexico; lcsandovalh@gmail.com \\ 4 Departamento de Ingeniería Industrial, Tecnológico Nacional de México/Instituto Tecnológico Superior de \\ Xalapa, Sección 5A Reserva Territorial S/N, Santa Bárbara, Xalapa, Veracruz 91096, Mexico; \\ carriodel@hotmail.com \\ * Correspondence: soydrew@hotmail.com
}

Received: 4 April 2019; Accepted: 16 April 2019; Published: 19 April 2019

check for updates

\begin{abstract}
The effects of Canna indica (P1), Pontederia sagittata (P2), and Spathiphyllum wallisii (P3) growing in different filter media materials (12 using porous river rock and 12 using tepezyl) on the seasonal removal of pollutants of wastewater using fill-and-drain constructed wetlands (FD-CWs) were investigated during 12 months. Three units of every media were planted with one plant of P1, P2, and P3, and three were kept unplanted. C. indica was the plant with higher growth than the other species, in both filter media. The species with more flower production were: C. indica $>$ P. sagittate $>$ S. wallisii. Reflecting similarly in the biomass of the plants, C. indica and P. sagittata showed more quantity of aerial and below ground biomass productivity than $S$. wallisii. With respect to the removal efficiency, both porous media were efficient in terms of pollutant removal performance $(p>0.05)$. However, removal efficiency showed a dependence on ornamental plants. The higher removal of chemical oxygen demand (COD), biochemical oxygen demand $\left(\mathrm{BOD}_{5}\right)$, total kjeldahl nitrogen (TKN), nitrates $\left(\mathrm{NO}_{3}{ }^{-}-\mathrm{N}\right)$, ammonium $\left(\mathrm{NH}_{4}{ }^{+}-\mathrm{N}\right)$, and phosphates $\left(\mathrm{PO}_{4}{ }^{-3}-\mathrm{P}\right)$ oscillated between $81 \%$ to $83 \%$, $80 \%$ to $84 \%, 61 \%$ to $69 \%, 61 \%$ to $68 \%, 65 \%$ to $71 \%, 62 \%$ to $68 \%$, and $66 \%$ to $69 \%$, respectively, in P1 and $\mathrm{P} 2$, removals $15 \%$ to $30 \%$ higher than $\mathrm{P} 3$. The removal in planted microcosms was significantly higher than the unplanted control units $(p=0.023)$. Nitrogen and phosphorous compounds were highly removed $(60 \%-80 \%)$ because in typical CWs, such pollutant removals are usually smaller, indicating the importance of FD-CWs on wastewater treatments using porous river rock and tepezyl as porous filter media. $\left(\mathrm{BOD}_{5}\right)$, chemical oxygen demand $(\mathrm{COD}),\left(\mathrm{NO}_{3}{ }^{-}-\mathrm{N}\right),\left(\mathrm{NH}_{4}{ }^{+}-\mathrm{N}\right),(\mathrm{TKN})$, and $\left(\mathrm{PO}_{4}{ }^{-3}-\mathrm{P}\right)$.
\end{abstract}

Keywords: removal pollutants; fill-and-drain constructed wetlands; tepezyl porous media; porous river rocks; ornamental plants

\section{Introduction}

Constructed wetlands (CWs) are environmentally friendly technologies that have demonstrated high efficiency in removing pollutants from wastewater [1-3]. This sustainable ecotechnology is based on natural wetland processes for the removal of contaminants, including physical, chemical, and biological routes, but in a more controlled environment compared with natural ecosystems $[1,4]$. 
The success of these systems depends on various factors, such as the hydraulic retention time, tolerance of the selected plants to the wastewater, and the optimum porous media for microorganism growth $[1,2,5]$. The water pollution problems and the growing potential of this sustainable technology demands the need for the optimization of CW designs. Various types of CWs can be used for the exclusion of toxic compounds (superficial or subsuperficial flow) $[1,5,6]$. In particular, the systems with saturated bed (subsuperficial flow) are suitable for this purpose. However, the water presence favors anaerobic conditions, which inhibit biological processes, such as nitrification, that require mainly aerobic conditions. Improved nitrogen compound removal involves both nitrification (in aerobic conditions) and denitrification (anaerobic conditions) processes. In the fill-and-drain (FD)-CWs (also commonly known as tidal flow CWs), the bed is intermittently saturated, which is related to the fill and drain phases. Such systems are mostly applied when increased oxygen transfer is needed [6], but may also be used to promote anaerobic processes when the holding phase is extended. The shortcomings of the FD-CWs are that the conditions in the system are not constantly anaerobic as compared to, for example, upflow CWs. It is thus necessary to evaluate the viability of FD-CWs using ornamental plants for the treatment of wastewater. The vegetation in CWs is one of the most important features; the vegetation can improve the water quality mainly by absorbing pollutants from the water, and have rich belowground organs (i.e., roots and rhizomes) in order to provide substrate for attached bacteria and the oxygenation of areas adjacent to roots and rhizomes [7,8]. In tropical and subtropical regions, the most popular vegetation used in constructed wetlands are Phragmites australis (Common reed), species of the genera, Typha (latifolia, angustifolia, domingensis, orientalis, and glauca), and Scirpus (e.g., lacustris, validus, californicus, and acutus) spp. [8]. However, there are local ornamental plants (plants grown or maintained for its aesthetic features, like its color, fragrance, flower production, attractive pattern, or design, are called ornamental plants) that have not been tested for their ability to remove pollutants, even though ornamental plants represent an economic alternative for developing countries, where wastewater treatment represents a large expenditure of the municipal budget [9-11]. Another important feature in treatment wetlands' design is the filter media. Some constructed wetlands are filled with expensive or uncommon materials as the substrate, such as zeolite [12,13], maerl (calcified seaweed) [14], wollastonite [15], shale [16], or cobbles [17]. However, in rural communities, where the economic conditions are deficient, it is worth taking into consideration the use of local materials and plants that have rarely been evaluated. Consequently, the main goals of this study were: (a) To examine the seasonal effect on growth and pollutant removal of different ornamental plants (Pontederia sagittata, Canna indica, and Spathiphyllum wallisii) with economical vision in the removal of pollutants using FD-CWs., and (b) to evaluate the use of different filter media (porous river rock and tepezyl) in the growth of plants and removal of pollutants in order to find the optimal design characteristics of constructed wetlands.

\section{Materials and Methods}

\subsection{Study Area}

The experimental FD-CWs were conducted in the rural locality of Pastorías (municipality of Actopan), Veracruz, Mexico ( $-96^{\circ} 57^{\prime} 08^{\prime \prime} \mathrm{N}$ and $19^{\circ} 55^{\prime} 83^{\prime \prime} \mathrm{S}$ ). The microcosms were established in a backyard with a transparent roof. Weather in the region is tropical with an annual precipitation of $947.1 \mathrm{~mm}$ and annual average temperature of $24.5^{\circ} \mathrm{C}\left(26.1,26.6,25.2\right.$, and $20.3^{\circ} \mathrm{C}$ in spring, summer, autumn, and winter, respectively, during the study from March 2015 to February 2016). The wastewater used was directly pumped from a community sewer (620 people). Three different ornamental plants were used in the FD-CWs: Canna indica; Pontederia sagittata, and Spathiphyllum wallisii. The plants with an individual height between 0.25 and $0.32 \mathrm{~m}$ were collected in riparian and creek zones near the study area. The porous river rocks (PR) and tepezyl (TS; sandy-like inert mineral of a fine grain that is lightweight and low cost, and is used in blocks for construction) were the only two different types of filter media employed. PR was collected from the riparian zone of the local river (Topiltepec) 
and was washed prior to its use in CWs. TS porous media was collected from the residues of building material supplied by some members of the community. The porosity of PR and TS was $50 \%$ and $40 \%$, respectively. Both filter media had an average diameter of $1.2 \mathrm{~cm}$.

\subsection{Design FD-CWs Microcosm}

The wastewater was filtered of big solids by a mash (pretreatment 1 ) and subsequently stored in a $1.1 \mathrm{~m}^{3}$ plastic tank where the water was sedimented during three days (pretreatment 2 ). After such processes, the water was used in the experimental units (constructed wetlands treatment). Twenty-four microcosms were constructed in cylindrical plastic containers $(0.36 \mathrm{~m}$ height and a $0.30 \mathrm{~m}$ diameter $)$ (Figure 1). Twelve microcosms contained PR and the remaining 12 were filled with TS as a porous media. The microcosms in every porous filter media were labeled as Pontederia sagittata (A, B, and C), Canna indica (A, B, and C), Spathiphyllum wallisii (A, B, and C), and control (unplanted) (A, B, and C). Two vegetation species were planted in each microcosm with flora. The species selected were plants that were easy to adapt and resistant to agents of weathering, considering its acclimatization in the zone, were collected in riparian and creek zones near the study area. The first 30 days after planting the vegetation, the experimental units were fed with tap drinking water. Starting from day 31 of the study, and for 30 days thereafter, the wastewater was added in proportions of $20 \%$ every 3 days in order to adapt the vegetation to the new water quality conditions. CWs were $100 \%$ fed with wastewater that was stored in the tank. In such an adaptation of the plants, it was not necessary to use any kind of fertilizer for the survival of the ornamental plants; the elements (nitrogen, phosphorous, etc.) present in the wastewater were the base of the natural nutrients for the plants. All microcosms' flow rates were adjusted for three days of the hydraulic retention time and $4 \mathrm{~cm} \mathrm{~d}^{-1}$ of the hydraulic loading retention rate, both during the filling phase in the subsurface down-flow wetland conditions. The fill-and-drain mode in CWs consisted of two phases: Filling phase and draining phase. Two hours every 3 days the experimental units were fed in the draining phase. For each microcosm experiment, the treated volume of wastewater was $\sim 3 \mathrm{~L} /$ day $^{-1}$.

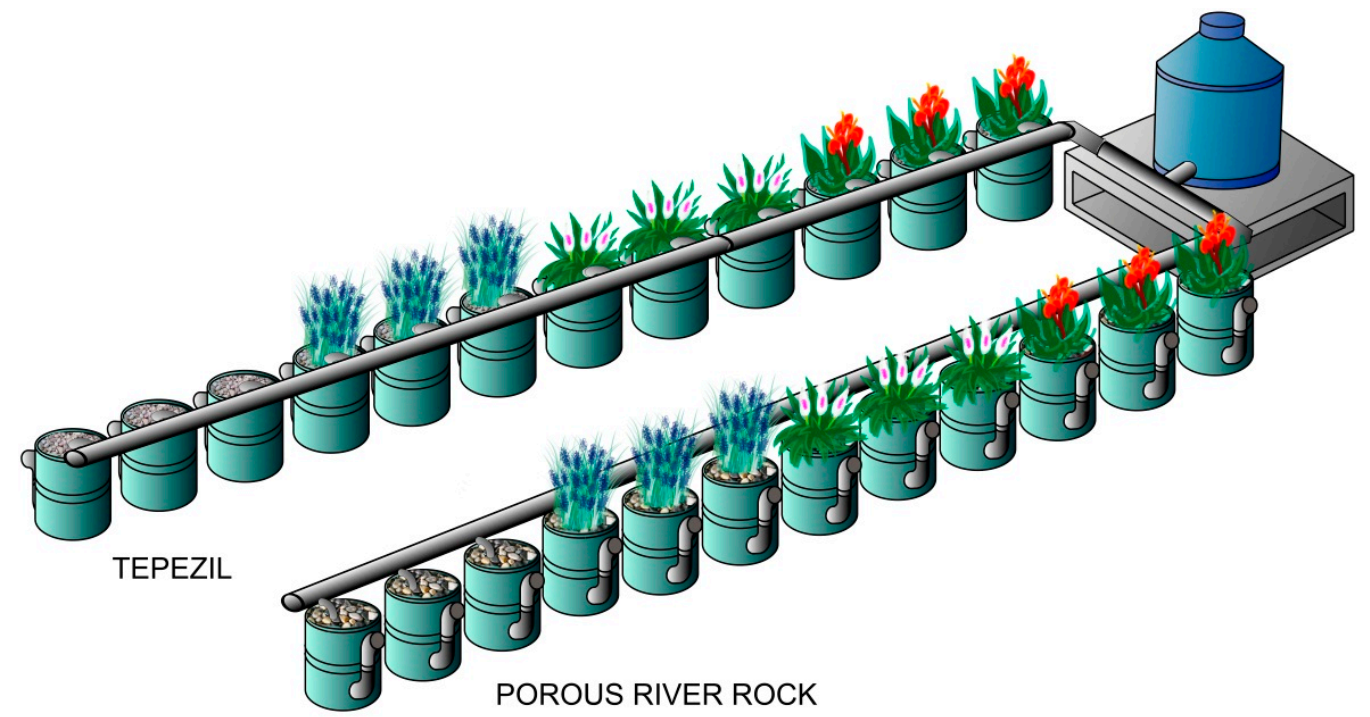

Figure 1. Scheme of constructed wetlands (CWs) used in this study.

\subsection{Physical-Chemical Parameters and Plant Growth Measurement}

The microcosms were studied from March 2015 to February 2016 for their efficiency on pollutants' removal. Surveyed water quality parameters were biochemical oxygen demand $\left(\mathrm{BOD}_{5}\right)$, chemical oxygen demand (COD), nitrates $\left(\mathrm{NO}_{3}{ }^{-}-\mathrm{N}\right)$, ammonium $\left(\mathrm{NH}_{4}{ }^{+}-\mathrm{N}\right)$, total kjeldahl nitrogen (TKN), and phosphates $\left(\mathrm{PO}_{4}{ }^{-3}-\mathrm{P}\right)$. Water samples $(250 \mathrm{~mL})$ were taken from the influent and effluent of each microcosm every 15 days (600 samples during one year) and analyzed in the laboratory according to 
standard methods [18]. The removal efficiency (\%) of the FD-CWs was calculated using the average of the inflow and outflow concentrations $[4,9,19]$. Other parameters measured were the redox potential (Eh) at a $15 \mathrm{~cm}$ depth in all the microcosms (near the rhizosphere zone in the planted units) with platinum electrodes according to Hernández et al. [20]. Total solids (TS), electrical conductivity (EC), $\mathrm{pH}$, and water temperature were measured with a YSI 550 multiparameter at each microcosm.

The individual plant height of each unit was measured every 15 days by tape, and then an average of the measurements was calculated. Four random plants of each species were harvested and their heights were recorded every month for biomass measurement. The plants were harvested and separated individually into root and aerial biomass (steam and leaves), after they were washed and dried at $40{ }^{\circ} \mathrm{C}$ to obtain constant weight [20].

\subsection{Statistical Analysis}

All statistical analyses were performed using SPSS software for Windows (SPSS Inc., Chicago, IL, USA, version 20). The significant differences between plants and porous media in pollutant removal were analyzed using two-way ANOVA followed by LSD (Least Significant Difference) tests (at $\alpha=0.05$ level). Values are presented as the mean \pm standard error.

\section{Results and Discussion}

The features of the wastewater under study are present in Table 1 . The $\mathrm{pH}$ during the experimental period was between 7.4 and 7.6 in the influent and controls, while in the microcosms with plants, the $\mathrm{pH}$ values decreased to nearly neutral values (6.9-7.2). This decrease is consistent with Romero [21], who observed that bacteria receive sustenance from nitrification-denitrification reactions causing alkalinity reduction and such reactions can be intensive in the plants' presence. Dissolved oxygen (DO) showed a range between 1 and $4.8 \mathrm{mg} \mathrm{L}^{-1}$. The water temperature in the microcosms was between 18 and $19.7^{\circ} \mathrm{C}$. Many wetland processes, such as microbial mediated reactions, are affected by temperature, and some authors $[17,22]$ reported that the optimum temperature for the survival of microorganisms responsible for pollutant removal is within 15 and $30^{\circ} \mathrm{C}$, a range that involves our own observed values. The electrical conductivity (EC) of soil affects the ability of plants and microbes to process the waste material flowing into a constructed wetland. In this study, EC varied between 1013 and $1245 \mu \mathrm{S} / \mathrm{cm}$ (Table 1), the optimum range as a growth medium that favors the removal of pollutant processes [17]. The redox potential changed in microcosm FD-CWs according to planted and unplanted systems, obtaining values of up to $300 \mathrm{mV}$ in the most superficial areas and near the roots of the plants, which was related to the oxygen supply of the rhizosphere zone. Among the unplanted systems, the values of Eh were slightly less oxidized (222 and $257 \mathrm{mV}$ ) than in the experimental units with vegetation (308-376 mV). The average measured value of the total suspended solids (TSS) in the influent was $211 \pm 16 \mathrm{mg} \mathrm{L}^{-1}$, a value higher than the control units (144 to $153 \mathrm{mg} \mathrm{L}^{-1}$; indicating the role of substrates as a filter of TSS), but values lesser of TSS were observed in the planted units (112 and $122 \mathrm{mg} \mathrm{L}^{-1}$ ), indicating the importance of the substrates together with the root of the plants as a retention of TSS. 
Table 1. Parameter concentrations at the inputs and outputs of the microcosm wetlands.

\begin{tabular}{|c|c|c|c|c|c|c|c|c|c|}
\hline \multirow[t]{3}{*}{ Parameter } & \multicolumn{9}{|c|}{ Wetland Plants in Different Substrates } \\
\hline & \multirow[t]{2}{*}{ Influent } & \multicolumn{2}{|c|}{ Canna indica } & \multicolumn{2}{|c|}{ Pontederia sagittata } & \multicolumn{2}{|c|}{ Spathiphyllum wallisii } & \multicolumn{2}{|c|}{ Control } \\
\hline & & PR & TS & PR & TS & PR & TS & PR & TS \\
\hline $\mathrm{pH}$ (pH units) & $7.6 \pm 0.2$ & $7.2 \pm 0.4$ & $7.1 \pm 0.9$ & $7.2 \pm 0.1$ & $7.2 \pm 0.8$ & $7.1 \pm 0.9$ & $6.9 \pm 0.6$ & $7.5 \pm 0.1$ & $7.4 \pm 0.1$ \\
\hline $\mathrm{DO}\left(\mathrm{mg} \mathrm{L}^{-1}\right)$ & $1.0 \pm 0.2$ & $4.2 \pm 0.8$ & $3.9 \pm 0.7$ & $4.2 \pm 0.6$ & $4.7 \pm 0.8$ & $4.8 \pm 1.2$ & $3.4 \pm 0.9$ & $1.5 \pm 0.2$ & $1.3 \pm 0.2$ \\
\hline Temperature $\left({ }^{\circ} \mathrm{C}\right)$ & $18.5 \pm 0.7$ & $19.1 \pm 0.9$ & $19.2 \pm 1.8$ & $19.4 \pm 0.9$ & $19.3 \pm 0.7$ & $18.2 \pm 1.4$ & $18.6 \pm 0.8$ & $19.7 \pm 0.6$ & $19.7 \pm 0.4$ \\
\hline $\mathrm{EC}(\mu \mathrm{S} / \mathrm{cm})$ & $1151 \pm 143$ & $1155 \pm 101$ & $1212 \pm 139$ & $1124 \pm 161$ & $1245 \pm 67$ & $1124.2 \pm 98$ & $1130.8 \pm 110$ & $1126 \pm 130$ & $1013.8 \pm 77$ \\
\hline Eh to $0.10 \mathrm{~m}$ depth & ND & $318.6 \pm 34$ & $317.5 \pm 43$ & $356.6 \pm 33$ & $371.8 \pm 24$ & $309.6 \pm 58$ & $308.1 \pm 26$ & $222.5 \pm 20$ & $257.84 \pm 18$ \\
\hline TSS $\left(\mathrm{mg} / \mathrm{L}^{-1}\right)$ & $211 \pm 16$ & $112 \pm 19$ & $117 \pm 41$ & $114 \pm 36$ & $118 \pm 52$ & $122 \pm 38$ & $112 \pm 35$ & $144 \pm 42$ & $153 \pm 44$ \\
\hline
\end{tabular}

Values are given as the average \pm standard error $(n=72)$. PR: microcosms with porous river rock, TS: microcosms with tepezyl. ND $=$ Not determined. 


\subsection{Plant Height and Biomass Changes}

The individual plant height change is shown in Figure 2. C. indica was the plant with higher growth than the other species, in both filter media. The maximum heights were 1.25 and $1.18 \mathrm{~m}$ in PR and TS filters, increasing almost $1 \mathrm{~m}$ of height during the study. Pontederia sagittatas howed lower increments in the height than $C$. indica. In both filters, the maximum height was $0.8 \mathrm{~m}$, increasing almost $0.6 \mathrm{~m}$ from March 2015 to February 2016. S. wallisii plants grew up to just $0.22 \mathrm{~m}$ during the study in both filter media. In general, the adaptation of plants was good; the wetland conditions did not affect their survival, becoming an important feature for the use of plants in constructed wetlands.

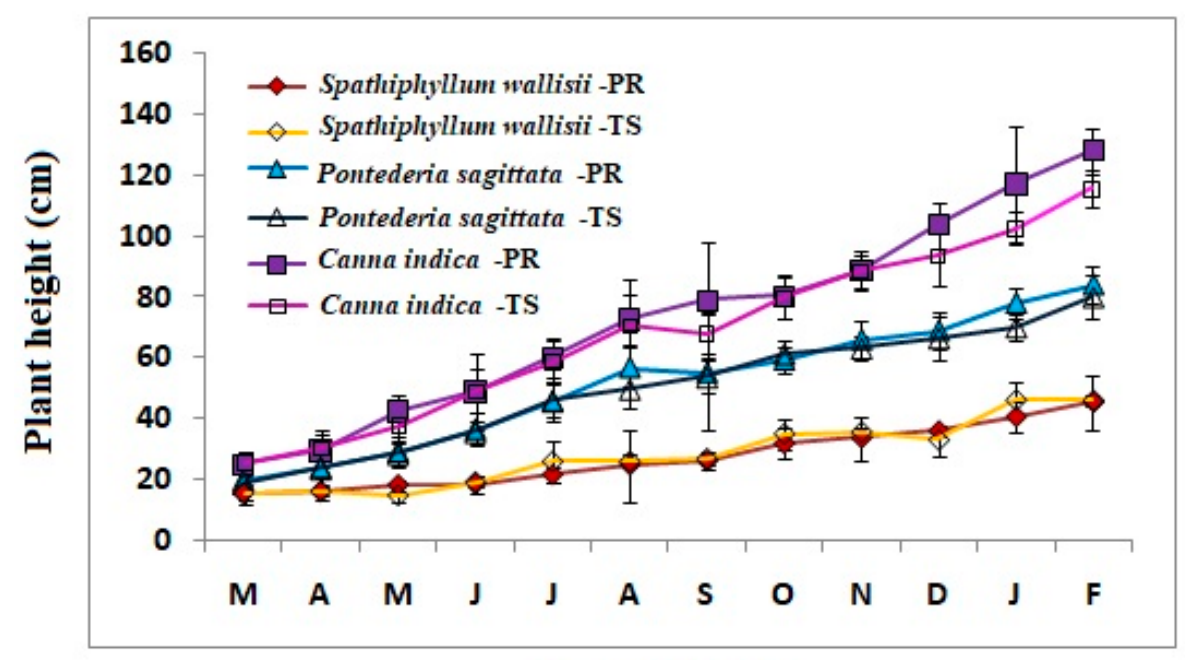

Time (month)

Figure 2. Individual plant height curve change with time.

Physical observations on the vegetation were evaluated during the study according to the wilting degree, growth situation of stems and leaves, diseases and pests, and flower production (Table 2). C. indica and S. wallisii were the plants without symptoms and considered the best, while P. sagittata showed some yellow leaves, pests, and diseases during the adaptation period (three weeks), but such conditions did not affect the flower production. The species with greater flower production were: C. indica $>$ P. sagittate $>$ S. wallisii. The last species, the one with less flower production, was related to the direct exposure to the sun (failed to adapt easily to CWs). Given that S. wallisii species are more likely to adapt in shadowed areas [23], the data observed in this study because of their use in CWs is not widely documented. However, it is important to mention that the adaptation of $S$. wallisii in CW conditions is an opportunity to stimulate the use of eco technologies; for example, removing pollutants and creating an esthetic landscape of the system with species flowers in CWs in backyards or in big areas for the production of plants and the potential of selling these plants as living specimens for interior design. In tropical regions, where temperatures range between 20 to $32{ }^{\circ} \mathrm{C}$, Conover [24] recommended the use of shadow mesh over the CW for better Spathiphyllum production. Studies with S. wallisii in CWs without direct exposure to the sun are necessary in future experiments. In the case of C. indica and P. sagittata, these are species more typical of wet soils and both are likely to adapt to direct exposure to the sun. 
Table 2. Growth characteristics of plants.

\begin{tabular}{cccccc}
\hline Plant & $\begin{array}{c}\text { Filter } \\
\text { Media }\end{array}$ & $\begin{array}{c}\text { Wilting Degree } \\
\text { (Number of } \\
\text { Plants) }\end{array}$ & $\begin{array}{c}\text { Growth Characteristics } \\
\text { Stems-Leaves-Flowers }\end{array}$ & $\begin{array}{c}\text { Diseases and } \\
\text { Pests }\end{array}$ & $\begin{array}{c}\text { Number of } \\
\text { Flowers during } \\
\text { the Study }\end{array}$ \\
\hline \multirow{2}{*}{ Canna indica } & PR & 0 & - & - & - \\
Pontederia & TS & 0 & - & $X 2$ \\
sagittata & PR & 0 & $X$ & $X$ & 29 \\
\hline Spathiphyllum & TS & 0 & - & - & 31 \\
wallisii & TS & 1 & - & - & 9 \\
\hline
\end{tabular}

${ }^{a}$ Growth characteristics of stems and leaves: -, plant grew normally; $X$, upper leaves withered; $X X$, the leaves of the whole individual plant turned yellow. ${ }^{b}$ Diseases and pests: -, no diseases and pests; $X$, slightly diseases and pests; $\mathrm{XX}$, serious diseases and pests.

With regard to the biomass of plants, the porous media material did not have a significant effect on the above or below ground biomass production $(p=0.084,0.076$; Figure 3$)$. However, there was a significant effect between different plants on biomass $(p=0.012)$, i.e., C. indica and P. sagittata showed a greater quantity of aerial and below ground biomass productivity than $S$. wallisii, similar to the height of plants observed in Figure 2, which could be reflected in the findings about the removal of pollutants of this study. Both characteristics are important for the selection of constructed wetland plants [25]. By having different ornamental plants in the CWs, the treatment system will be more attractive aesthetically and the function of the removal of pollutants is active. In another study with ornamental plants (Zantedeschia aethiopica and Alpinia purpurata) growing in CWs, the biomass production was similar to the findings in this study [26,27]. However, using plants of natural wetlands (Typha spp., Juncus sp.), biomass production has been reported to be higher in short time periods $[28,29]$. Such differences are common because ornamental plants are not typical of wetlands, and the production of biomass require adaptation (longer periods that natural plants) of the plants in the constructed wetland conditions (wastewater, material filter, and environmental conditions).

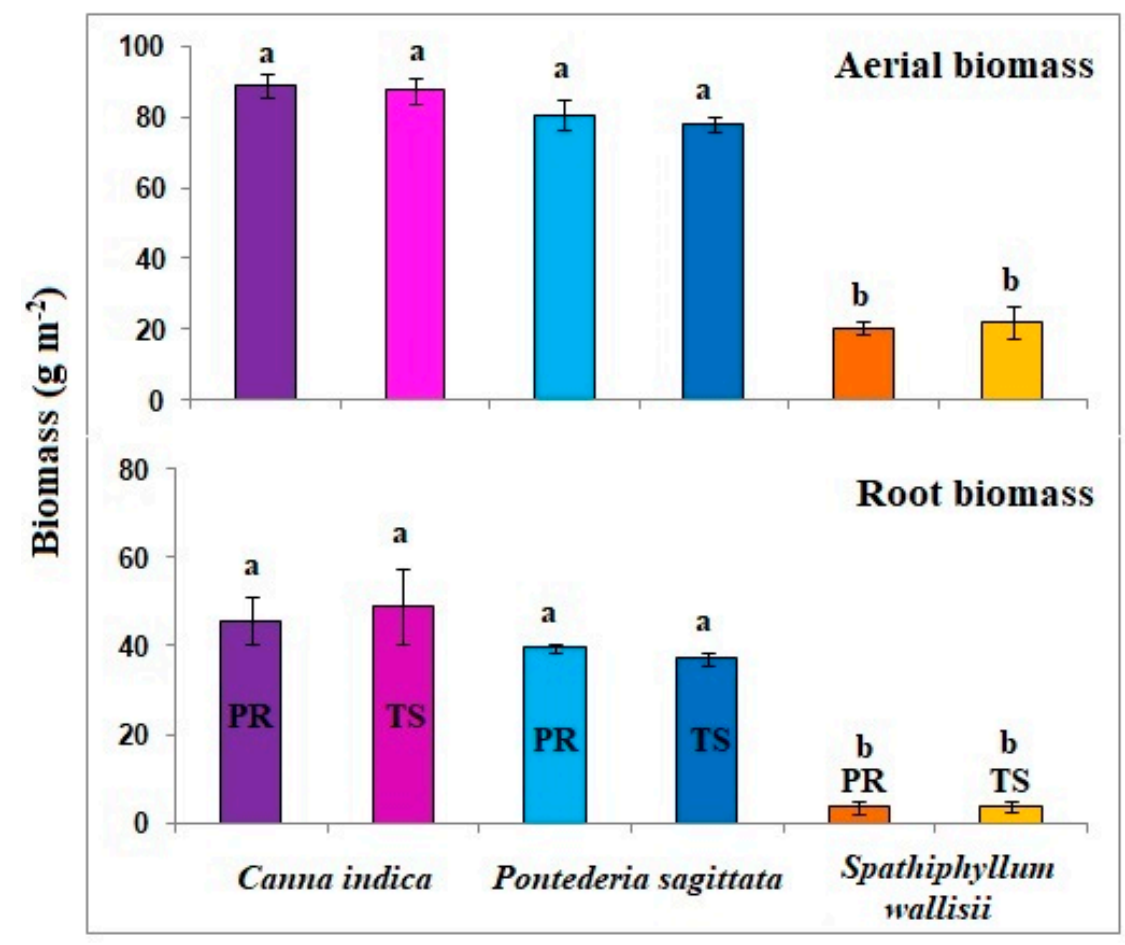

Figure 3. Effect of substrate media and plants on biomass production of different ornamental vegetation. $\mathrm{PR}=$ Porous river rock substrate, $\mathrm{TS}=$ Tepezyl substrate. Values are average \pm standard error. Different letters indicate significant differences $(p<0.05)$. 


\subsection{Nutrient Removal}

Influent and effluent concentrations and percent removal for $\mathrm{COD}, \mathrm{BOD}_{5}, \mathrm{TKN}, \mathrm{NO}_{3}{ }^{-}-\mathrm{N}, \mathrm{NH}_{4}{ }^{+}-\mathrm{N}$, and $\mathrm{PO}_{4}^{-3}-\mathrm{P}$ are summarized in Table 3. The respective mean influent water concentrations for the physic-chemical parameters were $375,298.3,60.2,8.88,30.06$, and $9.51 \mathrm{mg} \mathrm{L}^{-1}$. The corresponding removal oscillated within $28 \%$ to $73 \%, 44 \%$ to $83 \%, 19 \%$ to $69 \%, 18 \%$ to $7 \%, 31 \%$ to $68 \%$, and $18 \%$ to $69 \%$, respectively. The porous media did show any differences in the removal $(p \geq 0.05)$; both filter materials were excellent at removing pollutants of the wastewater. In the presence of vegetation in the experimental units, for all parameters measured as pollutants, the removals were between $15 \%$ and $50 \%$ higher than CWs without plants, indicating the phytoremediation influence.

The CWs with $P$. sagittata and $C$. indica were the microcosms where the removal efficiency was higher compared with units containing $S$. wallisii and units without vegetation for all parameters measured. The differences within plants are related to the lesser growth of $S$. wallisii and the slow adaptation of such species affected by the exposure to the sunlight. The positive effect on the removal of pollutants by the plants is related to what some authors have stated [6,30], with it being found that planted wetlands out-perform un-planted controls mainly because in the presence of plants, the rhizosphere area functions as a zone for the attachment of microorganism communities that remove pollutants, release gas, and exudate carbon, thus creating aerobic niches, avoiding re-suspension of nutrients and sludge, and increasing aerobic degradation. This activity was confirmed with the Eh values (Table 1), where more aerobic conditions in planted microcosms were observed (308-357 mV) compared with unplanted microcosms (222-258 mV), such redox conditions in microcosms with plants can favor the removal of nitrogen by nitrification.

On the other hand, nitrogen and phosphorous compounds are macronutrients for plants and microorganisms. Thus, a certain amount of $\mathrm{N}$ and $\mathrm{P}$ could serve for biomass synthesis, and thus, it is expected that there will be a higher removal in microcosms with plants than in unplanted systems. Other routes of nitrogen removal in CWs (partial nitrification-denitrification, anammox, dissimilatory nitrate reduction, and Canon process) need to be evaluated in order to identify the complete panorama on nitrogen removal as described by Saeed and Sun [31] and Mitsch and Gosselink [32]. In the case of $\mathrm{COD}$ and $\mathrm{BOD}_{5}$, a high biodegradability of organic material is expected when the relation $\mathrm{BOD}_{5} / \mathrm{COD}$ is close to 1 . In this study, the value was 1.25 [33]), with the observed removal values oscillating between $52 \%$ and $73 \%$ for COD and $67 \%$ and $83 \%$ for $\mathrm{BOD}_{5}$ (Table 3 ). The values obtained revealed that the water was considered as not being heavily contaminated and was almost acceptable in quality, according to the references of the Mexican National Water Commission [34]. This Commission has been monitoring the water quality of surface water since 1974 based on $\mathrm{COD}, \mathrm{BOD}_{5}$, and TSS parameters.

Besides, in studies using gravel with typical plants of wetlands (Cyperus, Phragmites, and Typha spp.), the removal of pollutants was similar to those obtained in this study, mainly using P. sagittata and C. indica (Table 4). 
Table 3. Water quality parameters in the influent and effluent, and mean removal percentages in the microcosms $(n=600)$.

\begin{tabular}{|c|c|c|c|c|c|c|c|c|}
\hline \multirow[t]{3}{*}{ Parameter } & \multicolumn{8}{|c|}{ Wetland Plants in Different Substrates } \\
\hline & \multicolumn{2}{|c|}{ Canna indica } & \multicolumn{2}{|c|}{ Pontederia sagittata } & \multicolumn{2}{|c|}{ Spathiphyllum wallisii } & \multicolumn{2}{|c|}{ Control } \\
\hline & PR & TS & PR & TS & PR & TS & PR & TS \\
\hline \multicolumn{9}{|l|}{ COD } \\
\hline IC & \multicolumn{8}{|c|}{$375 \pm 72.8$} \\
\hline EC & $70.7 \pm 19.8$ & $67.9 \pm 20.2$ & $65.6 \pm 16.9$ & $62.7 \pm 12.8$ & $124.6 \pm 12.8$ & $110.3 \pm 13.3$ & $205.6 \pm 21.9$ & $209.4 \pm 20.5$ \\
\hline Removal (\%) & $81.1 \pm 18.4^{\mathrm{a}}$ & $81.9 \pm 22.6^{\mathrm{a}}$ & $82.5 \pm 16.5^{a}$ & $83.3 \pm 17.9^{a}$ & $66.8 \pm 19.3^{b}$ & $70.6 \pm 11.3^{b}$ & $45.2 \pm 14.1^{c}$ & $44.2 \pm 16.9^{c}$ \\
\hline \multicolumn{9}{|l|}{$\mathrm{BOD}_{5}$} \\
\hline $\mathrm{EC}$ & $82.2 \pm 18.4$ & $80.6 \pm 20.1$ & $82.6 \pm 22.6$ & $83.9 \pm 31.2$ & $104.8 \pm 18.8$ & $100.6 \pm 21.9$ & $200.6 \pm 28.4$ & $212.4 \pm 29.6$ \\
\hline Removal (\%) & $72.4 \pm 22.6^{\mathrm{a}}$ & $73.0 \pm 32.2^{a}$ & $72.3 \pm 26.3^{a}$ & $71.8 \pm 12.9^{a}$ & $54.8 \pm 16.6^{\mathrm{b}}$ & $52.9 \pm 12.5^{\mathrm{b}}$ & $32.8 \pm 16.4^{\mathrm{c}}$ & $28.8 \pm 18.1^{\mathrm{C}}$ \\
\hline \multicolumn{9}{|l|}{ TKN } \\
\hline IC & \multicolumn{8}{|c|}{$60.2 \pm 09.7$} \\
\hline $\mathrm{EC}$ & $20.2 \pm 06.8$ & $19.5 \pm 10.1$ & $18.6 \pm 12.3$ & $23.1 \pm 11.6$ & $34.5 \pm 09.7$ & $32.6 \pm 10.9$ & $45.7 \pm 08.4$ & $48.7 \pm 09.0$ \\
\hline Removal (\%) & $66.4 \pm 12.1^{a}$ & $67.6 \pm 11.4^{a}$ & $69.1 \pm 10.3^{a}$ & $61.6 \pm 12.9^{\mathrm{a}}$ & $42.7 \pm 16.6^{b}$ & $45.8 \pm 12.5^{b}$ & $24.1 \pm 16.4^{c}$ & $19.1 \pm 18.1^{c}$ \\
\hline \multicolumn{9}{|l|}{$\mathrm{NO}_{3}^{-}-\mathrm{N}$} \\
\hline IC & \multicolumn{8}{|c|}{$8.88 \pm 0.24$} \\
\hline $\mathrm{EC}$ & $3.06 \pm 0.61$ & $2.85 \pm 0.16$ & $2.56 \pm 0.92$ & $2.82 \pm 0.83$ & $2.81 \pm 0.64$ & $5.78 \pm 0.72$ & $7.13 \pm 0.33$ & $7.23 \pm 0.24$ \\
\hline \multicolumn{9}{|l|}{$\mathrm{NH}_{4}^{+}-\mathrm{N}$} \\
\hline IC & \multicolumn{8}{|c|}{$30.06 \pm 0.64$} \\
\hline $\mathrm{EC}$ & $10.08 \pm 0.17$ & $10.14 \pm 0.22$ & $10.0 \pm 0.32$ & $10.06 \pm 0.30$ & $10.49 \pm 0.29$ & $10.54 \pm 0.31$ & $20.11 \pm 0.31$ & $20.04 \pm 0.32$ \\
\hline Removal (\%) & $64.7 \pm 14.1^{a}$ & $62.7 \pm 11.3^{a}$ & $67.6 \pm 12.2^{a}$ & $65.4 \pm 13.6^{\mathrm{a}}$ & $51.3 \pm 12.1^{b}$ & $49.7 \pm 11.2 b^{b}$ & $31.0 \pm 04.1^{\mathrm{c}}$ & $33.3 \pm 03.5^{c}$ \\
\hline \multicolumn{9}{|l|}{$\mathrm{PO}_{4}^{-3}-\mathrm{P}$} \\
\hline $\mathrm{IC}$ & \multicolumn{8}{|c|}{$9.51 \pm 0.97$} \\
\hline $\mathrm{EC}$ & $3.22 \pm 0.19$ & $3.01 \pm 0.33$ & $2.92 \pm 0.22$ & $3.06 \pm 0.41$ & $4.86 \pm 0.67$ & $4.26 \pm 0.78$ & $7.54 \pm 0.48$ & $7.74 \pm 0.45$ \\
\hline Removal (\%) & $66.1 \pm 4.6^{\mathrm{a}}$ & $68.3 \pm 5.8^{a}$ & $69.3 \pm 6.6^{\mathrm{a}}$ & $67.8 \pm 6.1^{a}$ & $48.9 \pm 9.4 \mathrm{~b}$ & $55.2 \pm 8.3^{b}$ & $20.9 \pm 2.8^{c}$ & $18.8 \pm 1.8^{c}$ \\
\hline
\end{tabular}

$\mathrm{IC}=$ Influent concentration $\left(\mathrm{mg} / \mathrm{L}^{-1}\right), \mathrm{EC}=$ Effluent concentration $\left(\mathrm{mg} / \mathrm{L}^{-1}\right)$. Values are average \pm Standard error, different letters indicate significant differences between the columns at $5 \%$ significance level PR: microcosms with porous river rock, TS: microcosms with tepezyl. 
Is important to describe that similar to this study, other works have reported a high removal efficiency of pollutants by growing ornamental plants in CWs (Table 4). For example, Olguín et al. [4] used Pontederia sagittata for the removal of diluted sugarcane molasses, using volcanic gravel as substrate, showing removals of organic matter between $80 \%$ and $85 \%$. Such results revealed that TS and PR should be used for similar removals, without the necessity of purchasing volcanic gravel, and allowing the reuse of TS of residues in construction. Besides, in this study, the molasses was diluted, a situation that was not necessary in this study. Another case is the study by Calheiros et al. [35], who reported that the use of ornamental flowering plants (Canna indica, Iris pseudacorus) and typical vegetation of natural wetlands (Typha latifolia, Phrgamites australis), grown in expanded clay (Filtralite ${ }^{\circledR} \mathrm{MR}$ ) as the substrate, in treating tannery wastewater showed COD reductions of $41 \%$ to $73 \%$ and $\mathrm{BOD}_{5}$ reductions of $41 \%$ to $58 \%$. Furthermore, the plants from natural wetlands were the only plants that were able to establish successfully. In this study, the ornamental flowering plants revealed a removal efficiency when grown in TS and PR substrates, reinforcing the instructions of using such material as filters in CWs. On the other hand, Cui et al. [36], using coal burn slag, blast furnace slag, and sand slag as filter media and plants of Canna indica, reported that in one year of study, $60 \%$ of phosphorous and ammonium was removed. In this study, the removals of the same parameters was similar in the presence of Pontederia s. and Canna i., with the difference in the substrate of reuse (TS), and PR was easy to obtain in areas with rivers. In an experimental study, Macci et al. [37] reported removals of nitrogen and phosphorous by $63 \%$ to $67 \%$ using gravel as the substrate and Canna indica. Those studies showed the importance of plants and substrates in the removal of pollutants in CWs, and reported removal efficiencies similar to those reported in this study with TS and PR, thus highlighting such substrates should be considered in new CW design.

Another aspect that can be considered for future studies is the use of S. wallisii in polyculture CWs, where the position of this species could be close to the effluent. It is important to consider that in the entrance, there are more charges of nutrients and it will be more difficult for this plant to uptake, given the fact that this species was the least adapted to CWs according to the growth measures (Figure 2; Figure 3). While in the final area of a cell of CWs, the charge of nutrients is low, a characteristic that may be feasible for the better growth of ornamental plants, such as $S$. wallisii $[38,39]$.

Table 4. Comparison of removal pollutants within different plants of natural wetlands versus the ornamental plants used in this study.

\begin{tabular}{|c|c|c|c|c|c|c|c|}
\hline \multirow{2}{*}{ Plants } & \multicolumn{5}{|c|}{ Parameters (Removal \%) } & \multirow{2}{*}{$\begin{array}{l}\text { Filter } \\
\text { Media }\end{array}$} & \multirow{2}{*}{ Source } \\
\hline & $\mathrm{BOD}_{5}$ & COD & $\mathrm{NH}_{4}{ }^{+}-\mathrm{N}$ & $\mathrm{NO}_{3}{ }^{-}-\mathrm{N}$ & $\mathrm{PO}_{4}^{-3}-\mathrm{P}$ & & \\
\hline $\begin{array}{l}\text { Canna indica, Iris pseudacoru, } \\
\text { Typha latifolia, Phrgamites } \\
\text { australis }\end{array}$ & $41-58$ & $41-73$ & - & - & 70 & $\begin{array}{l}\text { expanded } \\
\text { clay }\end{array}$ & [35] \\
\hline Canna indica & - & - & 60 & - & 60 & $\begin{array}{l}\text { coal burn, } \\
\text { blast } \\
\text { furnace } \\
\text { and sand }\end{array}$ & [36] \\
\hline Canna indica & - & - & 67.4 & - & 63.5 & Gravel & [37] \\
\hline Cyperus ligularis & - & 69 & 38 & 58 & 26 & Gravel & [40] \\
\hline Cyperus esculentus & - & 59 & 36 & 50 & 42 & & [41] \\
\hline Typha sp. & 82 & - & - & 60 & 56 & PR & [25] \\
\hline Phragmites australis & - & 75 & 26 & - & 17 & Gravel & [42] \\
\hline Phragmites australis & 78 & 73 & 78 & 75 & 64 & Gravel & [43] \\
\hline Typha latifolia & 81 & 84 & 69 & 71 & 71 & Gravel & [43] \\
\hline Pontederia sagittata & 84.8 & 80.4 & 6.12 & 57.3 & 0 & $\begin{array}{c}\text { Volcanic } \\
\text { gravel }\end{array}$ & [4] \\
\hline & & & & $33-67$ & $54-70$ & Gravel & \\
\hline Canna indica & $72-73$ & $81-82$ & $62-65$ & $65-68$ & $66-68$ & PR and TS & This study \\
\hline Pontederia sagittata & $71-72$ & $82-83$ & $65-68$ & $68-71$ & $67-69$ & PR and TS & This study \\
\hline Spathiphyllum wallisii & $52-55$ & $66-71$ & $49-51$ & $34-35$ & $48-55$ & PR and TS & This study \\
\hline
\end{tabular}




\subsection{Climatic Conditions Effect}

No statistic effect $(p>0.05)$ of the removal of pollutants was observed after comparing within climatic seasons by species (Figure 4). Stein and Hook [44] reported that the net effect of seasonal variation in water treatment in wetlands is greater in winter, because along the season, the plant-mediated oxygen transfer is affected by cold temperatures. This occurs mainly in temperate zones, however, in the tropical areas, such as this study, all the seasons were similar in temperature (26.1, 26.6, 25.2, and $20.3^{\circ} \mathrm{C}$ in spring, summer, autumn, and winter, respectively). Also, DO and Eh in the water showed good conditions for the survival of microorganisms, and plant growth. Such conditions are important for the treatment of wastewater (Table 2). Allen et al. [45] only observed differences in the removal of pollutants in wetland microcosms when the temperature changed from $24{ }^{\circ} \mathrm{C}$ to $4{ }^{\circ} \mathrm{C}$, changes not observed in this study.

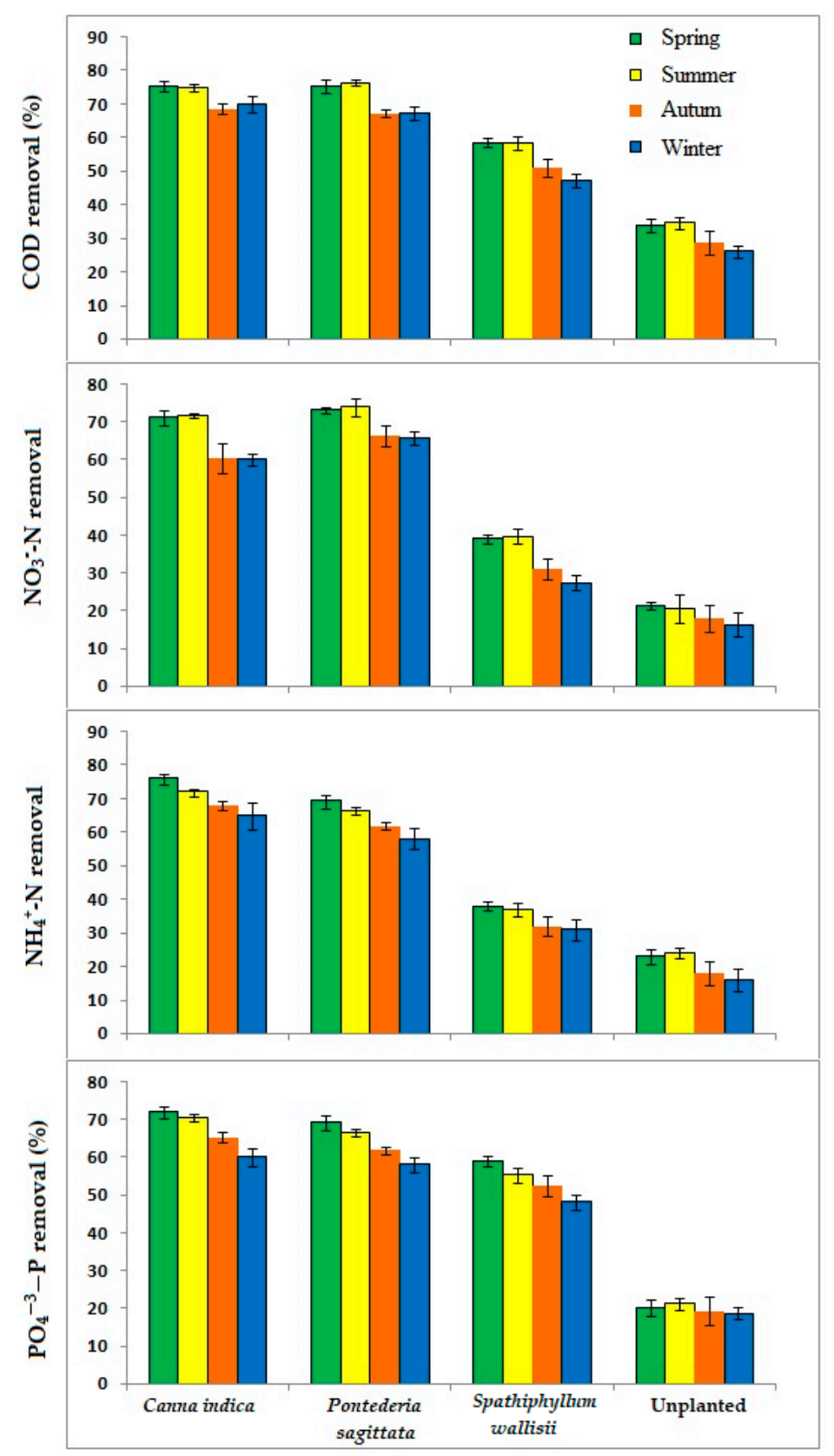

Figure 4. Seasonal pollutant removal in the CWs in the study using different plants. 


\section{Conclusions}

This study highlighted that FD-CWs using ornamental plants (Canna indica, Pontederia sagittata, Spatyphilum walisii) and PR or TS as a filter media, components rarely evaluated in CWs, such CWs design was ffective technologies for the removal of pollutants. In particular, using Canna indica and Pontederia sagittata with removal efficiencies of COD, $\mathrm{BOD}_{5}, \mathrm{TKN}, \mathrm{NO}_{3}{ }^{-}-\mathrm{N}, \mathrm{NH}_{4}{ }^{+}-\mathrm{N}$, and $\mathrm{PO}_{4}{ }^{-3}-\mathrm{P}$ around $70 \%$ to $85 \%$, showing the importance of fill and drainage design in CWs. The removal of phosphates in this study was similar to removals using typical substrates, indicating the importance of PR and TS as filter media. No statistic effect of the removal of pollutants was observed after comparing within climatic seasons by species related to the similar climatic conditions observed in tropical regions in all the study period. Consequently, this study suggests that Canna indica and Pontederia sagittata grown in tepezyl and porous rock of river in FD-CWs conditions are a good option for the removal of pollutants. Thus, its use is convenient in future construction of wetland design. This also suggests that additional studies should be carried out in tropical regions with ornamental plants to validate its commercial use as described in this paper. Also, new studies conducting a comparison of tepezyl and porous river rock with other commonly used filling materials on the pollutant removal and suitability for plant growth should be realized.

Author Contributions: M.V.-A., J.L.M.-M., J.M.C.-D. and S.A.Z.-C. conceived and designed the experiments; L.S.; M.V.-A. performed the experiments; S.A.Z.-C. and J.M.C.-D. analyzed the data; S.A.Z.-C. contributed with reagents/materials/analysis tools; L.S., M.V.-A. and J.L.M.-M. wrote the document.

Funding: This research received no external funding.

Acknowledgments: The authors thank Alvaro Ramírez for their help in the work and the El Colegio de Veracruz for generating the initiative for this project.

Conflicts of Interest: The authors declare no conflict of interest.

\section{References}

1. Vymazal, J. Constructed wetlands for treatment of industrial wastewaters: A review. Ecol. Eng. 2014, 73, 724-751. [CrossRef]

2. Toro-Vélez, A.F.; Madera-Parra, C.A.; Peña-Varón, M.R.; Lee, W.Y.; Bezares-Cruz, J.C.; Walker, W.S.; Cárdenas-Henao, H.; Quesada-Calderón, S.; García-Hernández, H.; Lens, P.N.L. BPA and NP removal from municipal wastewater by tropical horizontal subsurface constructed wetlands. Sci. Total Environ. 2016, 542, 93-101. [CrossRef]

3. Wu, S.; Carvalho, P.; Müller, J.; Remony, V.; Dong, R. Sanitation in constructed wetlands: A review on the removal of human pathogens and fecal indicators. Sci. Total Environ. 2016, 541, 8-22. [CrossRef] [PubMed]

4. Olguín, E.J.; Sánchez-Galván, G.; González-Portela, R.; López-Vela, M. Constructed wetland mesocosms for the treatment of diluted sugarcane molasses stillage from ethanol production using Pontederia sagittata. Water Res. 2008, 42, 3659-3666. [CrossRef] [PubMed]

5. Frazer-Williams, R. A review of the influence of design parameters on the performance of constructed wetlands. J. Chem. Eng. 2010, 25, 29-42. [CrossRef]

6. Sochacki, A.; Surmacz-Górska, J.; Guy, B.; Faure, O. Microcosm fill-and-drain constructed wetlands for the polishing of synthetic electroplanting wastewater. Chem. Eng. J. 2014, 251, 10-16. [CrossRef]

7. Wang, C.; Zheng, S.; Wang, P.; Qian, J. Effect of vegetation on the removal of contaminants in aquatic environments: A review. J. Hydrodyn. 2014, 26, 497-511. [CrossRef]

8. Vymazal, J. Plants used in constructed wetlands with horizontal subsurface flow: A review. Hydrobiologia 2011, 674, 133-156. [CrossRef]

9. Belmont, M.; Cantellano, E.; Thompson, S.; Williamson, M.; Sánchez, A.; Metcalfe, C. Treatment of domestic wastewater in a pilot-scale natural treatment system in central Mexico. Ecol. Eng. 2004, 23, 299-311. [CrossRef]

10. Zurita, F.; Anda, J.; Belmont, M. Performance of laboratory-scale wetlands planted with tropical ornamental plants to treat domestic wastewater. Water Qual. Res. J. Can. 2006, 41, 410-417. [CrossRef] 
11. Sandoval, L.; Zamora-Castro, S.A.; Vidal-Álvarez, M.; Marín-Muñiz, J.L. Role of Wetland Plants and Use of Ornamental Flowering Plants in Constructed Wetlands for Wastewater Treatment: A Review. Appl. Sci. 2019, 9, 685. [CrossRef]

12. Ríos, C.; Gutiérrez, L.; Aizaki, M. A case study on the use of constructed wetlands for the treatment of wastewater as an alternative for petroleoum industry. Bistua 2007, 5, 25-41.

13. Shuib, NK.; Baskaran, K.; Jegatheesan, V. Evaluating the performance of horizontal subsurface flow constructed wetlands using natural zeolite (escott). Int. J. Environ. Sci. Dev. 2011, 2, 311-315.

14. Gray, S.; Kinross, J.; Read, P.; Marland, A. The nutrient assimilative capacity of maerl as a substrate in constructed wetland systems for waste treatment. Water Res. 2000, 34, 2183-2190. [CrossRef]

15. Brooks, A.S.; Rozenwald, M.N.; Geohring, LD.; Lion, L.W.; Steenhuis, T.S. Phosphorus removal by wollastonite: A constructed wetland substrate. Ecol. Eng. 2000, 15, 121-132. [CrossRef]

16. Drizo, A.; Frost, C.; Smith, K. Phosphate and ammonium distribution in a pilot-scale constructed wetland with horizontal subsurface flow using shale as a substrate. Water Res. 2000, 34, 2483-2490. [CrossRef]

17. Akratos, C.; Tsihrintzis, V. Effect of temperature, HRT, vegetation and porous media on removal efficiency of pilot-scale horizontal subsurface flow constructed wetlands. Ecol. Eng. 2007, 29, 173-191. [CrossRef]

18. APHA. Standard Methods for the Examination of Water and Wastewater, 21st ed.; American Public Health Association: Washington, DC, USA, 2005.

19. Zhang, H.H.; Tian, J.S.; Zhang, Y.M.; Wu, Z.L.; Hu, Y.; Li, D.L. Removal of phosphorus and nitrogen from domestic wastewater using a mineralized refuse-based bioreactor. Environ. Technol. 2012, 33, 173-181. [CrossRef]

20. Hernández, M.E.; Marín-Muñiz, J.L.; Olguín, E.J. Effect of flood frequency and nutrient addition on plant growth and Total Petroleum Hydrocarbons removal in mangrove microcosm. J. Water Res. Prot. 2014, 6, 1716-1730. [CrossRef]

21. Romero, J.A. Tratamiento de Aguas Residuales. Teoría y Principios de Diseño, 3rd ed.; Escuela Colombiana de Ingeniería: Bogota, Colombia, 2013.

22. Kadlec, R.; Reddy, K.R. Temperature effects in treatment wetlands. Water Environ. Res. 2001, 73, 543-557. [CrossRef]

23. Wang, Q.; Chen, J. Variation in photosynthetic characteristics and leaf area contributes to Spathiphyllum cultivar differences in biomass production. Photosynthetica 2003, 41, 443-447. [CrossRef]

24. Conover, C.A. Foliage plants. In Introduction to Floriculture; Larson, R.A., Ed.; Academic Press: New York, NY, USA, 1992; pp. 569-601.

25. Liu, X.; Huang, S.; Tang, T.; Liu, X.; Scholz, X.M. Growth characteristics and nutrient removal capability of plants in subsurface vertical flow constructed wetlands. Ecol. Eng. 2012, 44, 189-198. [CrossRef]

26. Marín-Muñiz, J.L.; García-González, M.C.; Ruelas-Monjardín, L.C.; Moreno-Casasola, P. Influence of Different Porous Media and Ornamental Vegetation on Wastewater Pollutant Removal in Vertical Subsurface Flow Wetland Microcosms. Environ. Eng. Sci. 2018, 35, 88-94. [CrossRef]

27. Sandoval, L.; Marín-Muñiz, J.L.; Zamora-Castro, S.A.; Sandoval-Salas, F.; Alvarado-Lassman, A. Evaluation of Wastewater Treatment by Microcosms of Vertical Subsurface Wetlands in Partially Saturated Conditions Planted with Ornamental Plants and Filled with Mineral and Plastic Substrates. Int. J. Environ. Res. Public Health 2019, 16, 167. [CrossRef]

28. Rozema, E.; Gordon, R.; Zheng, Y. Harvesting plants in constructed wetlands to increase biomass production and $\mathrm{Na}^{+}$and $\mathrm{Cl}^{-}$removal from recycled greenhouse nutrient solution. Water Air Soil Pollut. 2016, 227, 136. [CrossRef]

29. Marín-Muñiz, J.L. Remoción de contaminantes de aguas residuales por medio de humedales artificiales establecidos en el municipio de Actopan, Veracruz, México. Rev. Mex. Ing. Quím. 2016, 15, 553-563.

30. Jethwa, K.; Bajpai, S. Role of plants in constructed wetlands (CWS): A review. J. Chem. Pharm. Sci. 2016, 2, 4-10.

31. Saeed, T.; Sun, G. A review on nitrogen and organics removal mechanisms in subsurface flow constructed wetlands: Dependency on environmental parameters, operating conditions and supporting media. J. Environ. Manag. 2012, 112, 429-448. [CrossRef] [PubMed]

32. Mitsch, W.J.; Gosselink, J. Wetlands; John Wiley and Sons Inc.: New York, NY, USA, 2015; Volume 5, 456p. 
33. Rivas, A.; Barceló-Quintal, I.; Moeller, G.E. Pollutant removal in a multi-stage municipal wastewater treatment system comprised of constructed wetlands and a maturation pond, in a temperate climate. Water Sci. Technol. 2011, 64, 980-987. [CrossRef]

34. Comisión Nacional del Agua (CONAGUA). Estadísticas del agua en México. Secretaría de Medio Ambiente y Recursos Naturales (SEMARNAT): México; p. 294. Available online: http://sina.conagua. gob.mx/publicaciones/EAM_2017.pdf (accessed on 2 April 2019).

35. Chalheiros, C.; Rangel, A.; Castro, P. Constructed wetland systems vegetated with different plants applied to the treatment of tannery wastewater. Water Res. 2007, 41, 1790-1798. [CrossRef] [PubMed]

36. Cui, L.; Ouyang, Y.; Lou, Q.; Yang, F.; Chen, Y.; Zhu, W.; Luo, S. Removal of nutrients from wastewater with Canna indica L. under different vertical-flow constructed wetland conditions. Ecol. Eng. 2010, 36, 1083-1088. [CrossRef]

37. Macci, C.; Peruzzi, E.; Doni, S.; Iannelli, R.; Masciandaro, G. Ornamental plants for micropollutant removal in wetland systems. Environ. Sci. Pollutt. Res. 2015, 22, 2406-2415. [CrossRef] [PubMed]

38. Langergraber, G. The role of plant uptake on the removal of organic matter and nutrients in subsurface flow constructed wetlands: A simulation study. Water Sci. Technol. 2005, 51, 213-223. [CrossRef] [PubMed]

39. Hernández, M.E. Ornamental wetlands with community participation for treatment of municipal wastewater in Mexico. Rinderesu 2016, 1, 1-12.

40. Casierra-Martínez, H.A.; Charris-Olmos, J.C.; Caselles-Osorio, A.; Parody-Muñoz, A.E. Organic matter and nutrients removal in tropical constructed wetlands using Cyperus ligularis (cyperaceae) and echinocloa colona (poaceae). Water Air Soil Pollut. 2017, 9, 228-338. [CrossRef]

41. Nwajuaku, I.I.; Okey-Onyesolu, C.F. Efficiency of Cyperus esculentus as a biofilter in treatment of domestic waste water. Saudi J. Eng. Technol. 2017, 2, 159-170. [CrossRef]

42. Abdelhakeem, S.; Aboulroos, S.; Kamel, M. Performance of a vertical subsurface flow constructed wetland under different operational conditions. J. Adv. Res. 2016, 7, 803-814. [CrossRef]

43. Papaevangelou, V.; Gikas, G.; Tsihrintzis, V. Effect of operational and design parameters on performance of pilot-scale horizontal subsurface flow constructed wetlands treating university campus wastewater. Environ. Sci. Pollut. Res. 2016, 23, 19504-19519. [CrossRef]

44. Stein, O.; Hook, P. Temperature, plants, and oxygen: How does season affect constructed wetland performance? J. Environ. Sci. Health Part A Toxic Hazard Subst. Environ. Eng. 2005, 40, 1331-1342. [CrossRef]

45. Allen, W.C.; Hook, P.B.; Biederman, J.A.; Stein, O.R. Temperature and wetland plant species effects on wastewater treatment and root zone oxidation. J. Environ. Qual. 2002, 31, 1010-1016. [CrossRef] 